高分子論文集 (Kobunshi Ronbunshu), Vol. 39, No. 12, pp. 807-811 (Dec., 1982)

\title{
双環オキサラクタムと 2-ピロリドンとの開環アニオン共重合
}

\author{
住友 宏 ${ }^{* 1} \cdot$ 橋本 和彦*1 $\cdot$ 別田 安弘 ${ }^{* 1, * 2}$
}

(受付 1982 年 6 月 18 日・審查終了 1982 年 8 月 24 日)

\begin{abstract}
要 旨 双環オキサラクタム，8-オキサ-6-アザビシクロ [3.2.1] オクタン-7-オン (以降 BOL と 略記する) と 2-ピロリドンとの塊状での開㛱アニオン共重合を, 触媒として 2-ピロリドンのカリウ

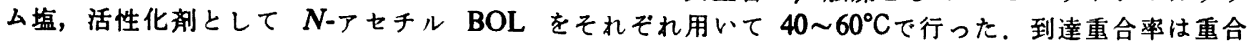
温度が $40^{\circ} \mathrm{C}$ の場合の方が. $60^{\circ} \mathrm{C}$ の場合よりも高かった。生成重合体の組成分析から, 本共重合条件

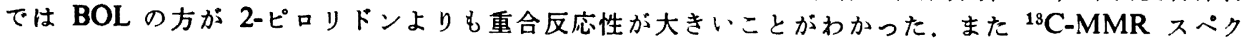
トル解析により，生成重合体が BOLと2-ピロリドンとのランダム共重合体であることを確認した。
\end{abstract}

\section{1 緒 霉}

双環オキサラクタム，8-オキサ-6-フザビシクロ[3.2.1] オクタン-7-オン（以降 BOL と略記する，1）は手近か に入手しやすい工業原料から得られる高い重合能をもつ モノマーで, $0^{\circ} \mathrm{C}$ 以下から $150^{\circ} \mathrm{C}$ の広い温度範囲で開環 重合して，テトラヒドロピラン環とアミド基とが交互配 列した構造のポリアミド 2 を容易に生成する、常温しか も溶液中でのアニオン重合によって高分子量の重合体が 得られる. 成膜も容易で, 親水性, 透水性に富むほか, 選択透過性など特改ある機能をもつことを明らかにして きだ〜8).

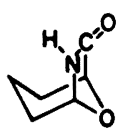

1

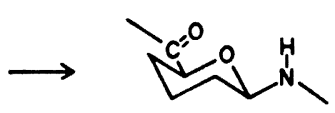

2
ยーカプロラクタムをはじめ 2-ピロリドン (3) などの単 環ラクタム類のアニオン開環重合に関する研究は数多く 行われてきたが日),10)，反応性の異なるラクタム間の共重 合は容易でないため, ラクタム同士の共重合研究は比較 的少ない(11) 18). BOL (1) の構造が7員環ラクタムと 5 員環ラクタムとの両方の骨格をもっていること，及び 1 が常温でも容易に溶液了ニオン重合するほど重合反応性 が高いことを考虑して，ここではまず 3 とのアニオン開 環共重合を検討した．触媒として3のカリウム塩（以下 K-Pyrdn と略記する)，活性化剂としてN-アセチル BOL をそれぞれ用いて，1 と 3 とを塊状で共重合させた。

*1 名古属大学農学部 (-464 名古屋市千種区不老町)

*2 現在は新和製作所（⿶247 横浜市戸塚区小菅ヶ谷町 1750)

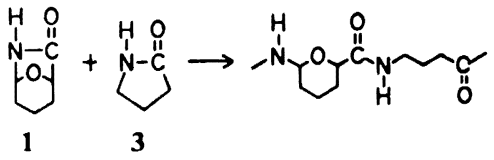

2 実呀方法

\section{1 試薄}

8-オキサ-6-アザビシクロ [3.2.1] オクタン-7-オン $(\mathrm{BOL}, 1)$ は既報の方法年, 3),7)に従って合成し，n-へキ廿 ン溶液から再結晶した後, 五酸化リン存在下で乾燥した (融点 91-92 $\mathrm{C}$ ). 2-ピロリドン (3) は，その 3 倍量のキ シレンとの混合物からキシレンをゆっくり常圧蒸留する ことにより含有する水を共沸させた後, 減圧蒸留した. 3 のカリウム塩 (K-Pyrdn) は文献 ${ }^{14)}$ 記載の方法により 調製し，ガラス試験管に入れて脱気封入し，使用直前ま で $-60^{\circ} \mathrm{C}$ で保存した. $N$-フセチル-8-オキサ-6-アザビ シクロ [3.2.1]オクタン-7-オン ( $N$-acetyl BOL) は, 1 と過剩の無水酢酸とから常法の゙により合成した2). 沸点 $103^{\circ} \mathrm{C} / 2 \mathrm{mmHg}$.

\section{2 重合方法}

(a) ジョイント付きガラス管中に所定量の 1 と 3 と を加え脱気用コックを装着し，脱気後乾燥窒素ガスで固 換した. 数回この操作を繰返した後减圧 $(2 \mathrm{mmHg})$ 下, $60^{\circ} \mathrm{C}$ で 2 3 時間加熱することによりモノマーを乾燥し た. 放冷後乾燥窒素ガス雾囲気下で所定量の K-Pyrdn を加え, 再び脱気用コックを装着して脱気しながら振り 混ぜて触媒をモノマー混合液に溶解させた. 最後に乾蜗 窒素ガス雾囲気下に $N$-アセチル BOL をマイクロシリ ンジで仕込んで, 凍結脱気後值ちに封管し, 所定温度の 恒温槽中に静置して重合させた. 
Table 1. Anionic bulk copolymerization of 8-oxa-6-azabicyclo[3.2.1]octan-7-one (BOL) with 2-pyrrolidone ${ }^{\text {a) }}$

\begin{tabular}{ccccccc}
\hline \hline $\begin{array}{c}\text { Exp. } \\
\text { No. }\end{array}$ & $\begin{array}{c}\text { BOL } \\
(\mathrm{g})\end{array}$ & $\begin{array}{c}\text { Mole } \\
\text { fraction of } \\
\text { BOL in feed }\end{array}$ & $\begin{array}{c}\text { Temp. } \\
\left({ }^{\circ} \mathrm{C}\right)\end{array}$ & $\begin{array}{c}\text { Polymer } \\
\text { yield } \\
(\%)\end{array}$ & $\begin{array}{c}{[\eta]^{\mathrm{b})}} \\
\begin{array}{c}\text { Mole fraction } \\
\text { of BOL unit } \\
\text { in copolymer }\end{array}\end{array}$ \\
\hline $1^{\mathrm{d})}$ & 1.77 & 1.00 & 60 & 61 & 1.00 & 1.00 \\
2 & 0.51 & 0.30 & 60 & 55 & $--^{\mathrm{e})}$ & 0.57 \\
3 & 0.29 & 0.20 & 60 & 44 & $-{ }^{\mathrm{e})}$ & 0.51 \\
4 & 0.16 & 0.10 & 60 & 39 & 0.26 & 0.18 \\
5 & 0 & 0 & 60 & 25 & $--^{\mathrm{e})}$ & 0 \\
6 & 1.30 & 0.30 & 40 & 60 & 0.36 & 0.60 \\
7 & 0.79 & 0.20 & 40 & 69 & 0.47 & 0.31 \\
8 & 0.37 & 0.10 & 40 & 82 & 0.48 & 0.13 \\
9 & 0 & 0 & 40 & 77 & 2.07 & 0 \\
\hline
\end{tabular}

K-Pyrdn, $3 \mathrm{~mol} \% /$ total monomer; $N$-acetyl BOL, $1 \mathrm{~mol} \% /$ total monomer; polymerization time, $72 \mathrm{hr}$.

b) In $m$-cresol at $25^{\circ} \mathrm{C}$.

c) Estimated from the relative peak intensity in ${ }^{1} \mathrm{H}$ NMR spectrum.

d) K-Pyrdn, $1 \mathrm{~mol} \% / \mathrm{BOL} ; \mathrm{N}$-acetyl BOL, $0.2 \mathrm{~mol} \% / \mathrm{BOL}$; polymerization time, $2 \mathrm{~h}$.

a) Partially insoluble in $m$-cresol.

(b) 重合初期から所定条件で重合させるためには，二 股の重合用ガラス管を用いた。 まず一ううのガラス管に雨 モノマーと N-アセチル BOL を，他方のガラス管には K-Pyrdn を（a) と同様の操作により仕込んだ. 窒温で 脱気と窒素ガスによる置換とを数回繰り返した後, 凍結 脱父を行い封管した。これを恒温槽中に浸漬し, 重合管 中の温度が恒温㡟中のそれに達してから，重合管を傾け て雨モノマーと活性化剂との混合液を触媒側のガラス管 一流し込み，振り混ぜて重合を開始させた。

\section{3 生成重合体の精製}

所定時間重合後重合管を開封し，アセトンを注入して ガラス棒でかくはんした，重合率が高くて生成物が固す ぎ場合は, 重合管の内径より少し小さい外径のドリ ル，またはェンドミルを重合管中に挿入し，回転させる ことにより生成物を切削した. 生成物を大過㮃のアセ卜 ン中に 15 時間以上室温で浸漬した後グラスフィルター 上に捕集し， $2 \mathrm{~mm} \mathrm{Hg}, 50^{\circ} \mathrm{C}$ で恒量になるまで乾燥し た.

\section{4 生成重合体のキャラクタリゼーション}

2.4.1 ${ }^{1}$ H NMR スペクトル 生成重合体の $8 \%$ ギ 酸水溶液を調製し，日本電子 (株) 製 JNM-MH-100 型 高分解能核磁気共鳴吸収装置を用い, $100 \mathrm{MHz}$ で室温 において測定した。内部標準としてテトラィチルシラン (TMS) を用いた.

2.4.2 ${ }^{13} \mathrm{C}$ NMR スペクトル $\quad$ 直径 $10 \mathrm{~mm}$ の試料管 に生成重合体の約 10\% 2,2, 2-トリフルオロエタノール 溶液と内部標準 TMS とを入れ，更に重水を入れた毛細 管をも入れて密封した．日本電子(株)製 JNM-FX-100型 フーリエ変換高分解能核磁気共鳴吸収装置を用い, 25

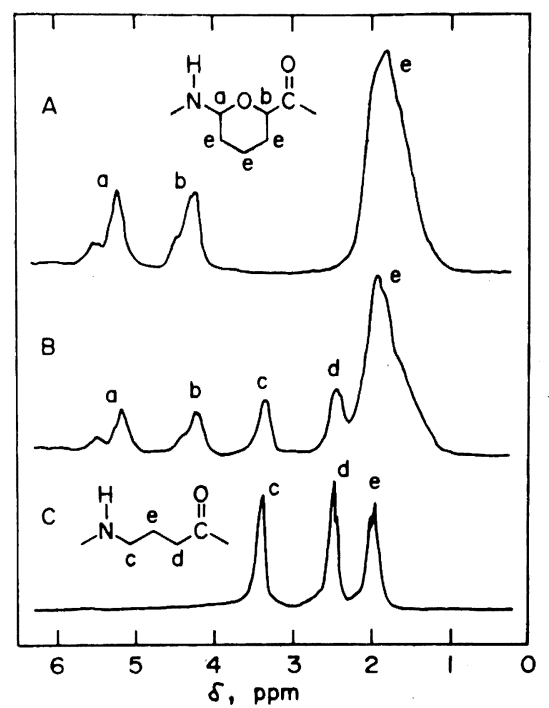

Fig. 1. ${ }^{1} \mathrm{H}$ NMR spectra of homopolymers and copolymer of $\mathrm{BOL}$ and 2-pyrrolidone ( $8 \%$ formic acid solution, room temperature, $100 \mathrm{MHz}$ ): $\mathrm{A}$, poly BOL; B, copolymer (mole fraction of BOL unit, 0.66); $\mathrm{C}$, poly (2-pyrrolidone).

$\mathrm{MHz}$ で $60^{\circ} \mathrm{C}$ において測定した.

2.4.3 溶液粘度 Ubbelohde 型粘度計を用い25士 $0.05^{\circ} \mathrm{C}$ に打いて $m$-クレゾール中, 約 $0.6 \mathrm{~g} / 100 \mathrm{ml}$ の 濃度から順次希釈した 4 濃度における粘度数 $\eta_{\mathrm{sp}} / \mathrm{c}$ を, 濃度 $c=0$ に外挿することにより極限粘度数 [ $\eta$ ] を求め た. 
双環オキサラクタムと 2-ピロリドンとの開環アニオン共重合

Table 2. Anionic bulk copolymerization of BOL with 2-pyrrolidone for short time ${ }^{a}$

\begin{tabular}{ccccccc}
\hline \hline $\begin{array}{c}\text { Exp. } \\
\text { No. }\end{array}$ & $\begin{array}{c}\text { BOL } \\
(\mathrm{g})\end{array}$ & $\begin{array}{c}\text { Mole fraction } \\
\text { of BOL } \\
\text { in feed }\end{array}$ & $\begin{array}{c}\text { Time } \\
(\mathrm{min})\end{array}$ & $\begin{array}{c}\text { Polymer } \\
\text { yield } \\
(\%)\end{array}$ & $\begin{array}{c}\text { Mole fraction } \\
\text { of BOL unit } \\
\text { in copolymer }{ }^{\mathrm{b})}\end{array}$ & $\begin{array}{c}\text { Mole fraction } \\
\text { of BOL in } \\
\text { residual } \\
\text { monomer }^{\mathrm{c})}\end{array}$ \\
\hline 10 & 0.25 & 0.50 & 1.5 & 24.1 & 0.93 & 0.39 \\
11 & 0.51 & 0.40 & 1.5 & 34.6 & 0.78 & 0.25 \\
12 & 0.37 & 0.20 & 2 & 15.8 & 0.75 & 0.13 \\
13 & 0.21 & 0.10 & 2 & 14.2 & 0.51 & 0.04 \\
14 & 0.12 & 0.05 & 2 & 3.4 & 0.31 & 0.04 \\
\hline
\end{tabular}

a) K-Pyrdn, $3 \mathrm{~mol} \% /$ total monomer; $N$-acetyl BOL, $1 \mathrm{~mol} \% /$ total monomer; polymerization temperature, $45^{\circ} \mathrm{C}$.

b) Estimated from the relative peak intensity in ${ }^{1} \mathrm{H}$ NMR spectrum.

c) Calculated from the compositions of the feed and copolymer and polymer yield.

2.4.4 熱分析 理学電機(株)製サーモフレックス 8001 型示差熱分析装置を用い, 昇温速度 $5^{\circ} \mathrm{C} / \mathrm{min}$, 感度 \pm 50 $\mu \mathrm{V}$ でアルミナを基準物質として示差熱分析を行った。

\section{3 結果と考察}

Table 1 に BOL (1) と 2-ピロリドン (3) との開政 アニオン共重合結果をそれらの単独重合結果とともに揭 げた. 触媒及び活性化㓮を全モノマーに刘してそれぞれ 3 モル\%及び 1 モル\%用い，仕込みモ, マー中のBOL のモル分率を変えて， $60^{\circ} \mathrm{C}$ 及び $40^{\circ} \mathrm{C} て ゙ 72$ 時間共重台 させたところ, 到達重合率はいずれもかなり高かった。 重合温度 $40^{\circ} \mathrm{C}$ の場合の方が $60^{\circ} \mathrm{C}$ の場合よりも到達重 合率が高く，特に仕込王モノマー中の 3 の含量が高い埸 合にその傾向が強かった。これは 3 の天井温度がかなり 低いこと ${ }^{18)}$ に起因するのであろう. 重合生成物の $m$-ク レジール中での極限粘度数测定結果は生成物がかなりの 高分子量であることを示す. $60^{\circ} \mathrm{C}$ で得られた重合体の 一部が $m$-クレゾールに一部不溶であった. 1 の単独ア ニオン重合を高温で長時間行って得た重合体は, 複雑な

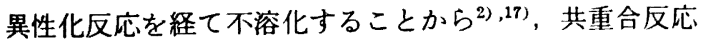
の場合も同様の反応が起こったものと思われる.

Fig. 1 に 1 と 3 とのアニオン共重合により得た重合 体の ${ }^{1}$ H NMR スペクトルを，それぞれの単独重合体の それらと比較した. 両モノマー単位が重台体中に存在し ていることは明らかであり，各ピークは図中に示したよ らに帰属できる。 ${ }^{1} \mathrm{H}$ NMR スペクトル中のピークの強 度比から, 生成重合体中の両モノマー単位の存在比を計 算し, Table 1 に掲げた. 重合体中の BOL 単位のモル 分率は，仕込みモノマー中のそれよりかなり高かった. 共重合により得た重合体の収量とこれらの組成比とから モノマー消費量を計算すると，Table 1 に揭げた共重合 実験の場合，ほとんどすべての BOL モノマーが消費さ れていることがわかる. すなわちこれらの重合条件で は、たとえ初期に雨モノマー単位がランダムに連なった

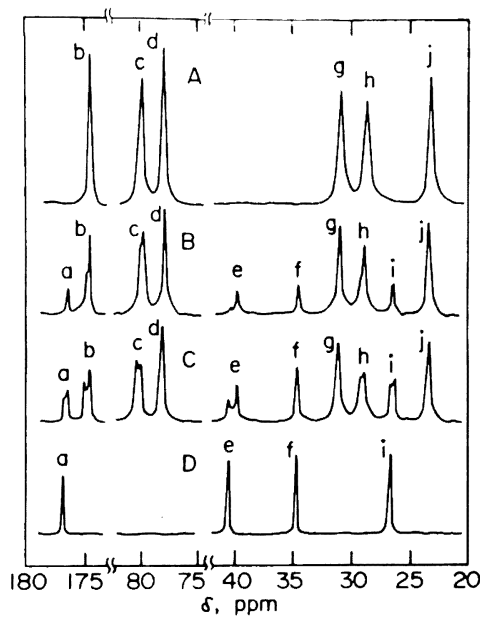

Fig. 2. ${ }^{13} \mathrm{C}$ NMR spectra of homopolymers and copolymer of BOL and 2-pyrrolidone $(10 \% 2,2,2-$ trifluoroethanol solution, $\left.60^{\circ} \mathrm{C}, 25 \mathrm{MHz}\right)$ : A, polyBOL; B, copolymer (mole fraction of BOL unit, 0.80 ); C, copolymer (mole fraction of BOL unit, $0.60)$; D, poly (2-pyrrolidone).

共重合体が生成したとしても，重合後期には3のほぼ単 独重合が谁行している可能性がある.

重合初期の生成物の構造を確認するため，短時間での 共重合反応を行い，Table 2 にまとめた．触媒と活性化 剂とを全モノマーに対してそれぞれ，3モル\%及び 1 モ ル\%用いると重合速度が非常に大きく，しかも10仕込 み比が高いほど重合速度が大きくなって重合反応の制御 がむずかしくなる．生成重合体中の BOL 単位は仕込み モノマー中のそれよりはるかに多い. 比較的重合初期て 停止させた共重合結果を，Mayo-Lewis の共重合組成式

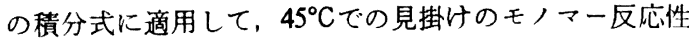
比 $r_{\mathrm{BOL}}=15 \pm 2$ 及び $r_{\mathrm{p} \mathrm{yrdn}}=0.09 \pm 0.06$ を得た. 1 の 
Table 3. Chemical shifts and assignments on ${ }^{13} \mathrm{C}$ NMR spectra of the homopolymers and copolymer of BOL and 2-pyrrolidone in Fig. $2^{a)}$

\begin{tabular}{|c|c|c|c|c|c|c|c|c|c|c|c|}
\hline \multirow{2}{*}{ Polymer } & \multirow{2}{*}{$\begin{array}{c}\text { Mole } \\
\text { fraction } \\
\text { of BOL } \\
\text { unit in } \\
\text { copolymer }\end{array}$} & \multicolumn{10}{|c|}{ Chemical shifts of peaks (ppm) } \\
\hline & & a & b & c & d & e & f & $\mathbf{g}$ & $\mathbf{h}$ & $\mathrm{i}$ & $\mathbf{j}$ \\
\hline Poly BOL & 1.00 & - & 174.70 & 79.96 & 78.11 & - & - & 31.11 & 28.90 & - & 23.46 \\
\hline Copolymerb) & 0.80 & 176.60 & 174.70 & 79.97 & 78.16 & $\left\{\begin{array}{l}39.81 \\
40.50\end{array}\right.$ & 34.65 & 31.19 & 29.00 & 26.46 & 23.49 \\
\hline Copolymer $^{\mathrm{c})}$ & 0.66 & $\left\{\begin{array}{l}176.55 \\
176.77\end{array}\right.$ & $\left\{\begin{array}{l}174.70 \\
175.13\end{array}\right.$ & $\left\{\begin{array}{l}80.02 \\
80.35\end{array}\right.$ & 78.21 & $\left\{\begin{array}{l}39.81 \\
40.50\end{array}\right.$ & 34.65 & 31.242 & 28.95 & $\left\{\begin{array}{l}26.46 \\
26.75\end{array}\right.$ & 23.49 \\
\hline Poly(2-pyrrolidone) & 0.00 & 176.96 & - & - & - & 40.57 & 34.87 & - & - & 26.75 & - \\
\hline
\end{tabular}

a) $10-15 \%$ 2,2,2-Trifluoroethanol solution, $60^{\circ} \mathrm{C}, 25 \mathrm{MHz}$.

b) Polymerization condition: mole fraction of $\mathrm{BOL}$ in feed, $0.30 ; \mathrm{K}-\mathrm{Pyrdn}, 1 \mathrm{~mol} \% /$ total monomer; $N$-acetyl BOL, $0.5 \mathrm{~mol} \% /$ total monomer; temperature, $40^{\circ} \mathrm{C}$; time, $30 \mathrm{~min}$. Yield, $33 \%$; [ $]$ ], 0.21 (in $m$-cresol at $\left.25^{\circ} \mathrm{C}\right)$.

c) Polymerization condition: mole fraction of BOL in feed, 0.20; K-Pyrdn, $1 \mathrm{~mol} \% /$ total monomer; $N$ acetyl BOL, $0.5 \mathrm{~mol} \% /$ total monomer; temperature, $40^{\circ} \mathrm{C}$; time, $150 \mathrm{~min}$. Yield, $34 \%$; $[\eta], 0.23$ (in $\mathrm{m}$ cresol at $25^{\circ} \mathrm{C}$ ).

万が 3 より重合反応性がかなり高いといえる.

Fig. 2 に 1 と 3 とのアニオン共重合により得た重合 体の ${ }^{13} \mathrm{C}$ NMR スペクトルをそれぞれの単独重合体のス ペクトルと比較し, Table 3 にはそれらのピークのケミ カルシフトをまとめた. 1 の単位中の炭素原子に帰属さ
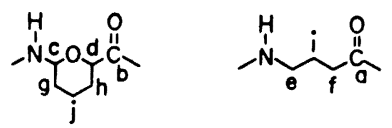

れるピークは, 1 のホモポリマーのスペクトルの場合と 同様に観察された。このうちカルボニル炭素原子, 及び アミド基の窒素原子に隣るメチン炭素原子に䚻属される ピーク b 及び c は 2 本に分裂し, しか子高磁場側のピ ークのケミカルシフトは1のホモポリマーのスペクトル 中の対応するピークのケミカルシフトと一致した. 他方 それぞれの低磁場側のピークは1のホモポリマーのスぺ クトル中にはなく，しかもそれらの前者に対する相対強 度は生成重合体中の 1 の単位の含量の低下寸るほど増加 した. 1 の単位中の炭素原子に㷌属できるその他のピー クも分裂こそしないが, そのケミカルシフトは1 の単位 の含量が低下するほど低磁場側へずれた．これらの結果 は, 生成重合体中で 1 の単位と $\mathbf{3}$ の単位とがランダムに 連なっていること,すなわち重合体中の 1 の単位の含量 か堿少するほど， 1 の単位が 3 の単位に隣る確率が増加 することを意味する. 3 の単位中の炭素原子に帰属され

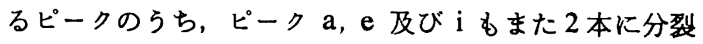
し，それぞれの低磁場側のピークのケミカルシフトが 3 のホモポリマーのスペクトル中の対応するピークのケミ
カルシフトと一致した．それゆえ残りの高磁場側のピー クが 1 の単位に隣接する 3 の単位中の炭素原子に帰属で きる、ピークの分離度がそれほど良くないので，両モノ マー単位の連鎖分布までは計算できないか， 1 の単位と 3 の単位とがかなりランダムに連なった共重合体が生成 していることがわかった．共重合体の示差熱分析に抹い て明確な融点を示さないこともこれを支持する.

1 とと-カプロラクタムとの塊状アニオン共重合を, そ のいずれのモノマーの単独アニオン重合す容易に起こ り，かつ高収率でポリアミドを生成する重合条件（触媒 $1 \mathrm{~mol} \%$, 活性化剤 $1 \mathrm{~mol} \%$, 温度 $110^{\circ} \mathrm{C}$, 時間 7 時間) で, 1 の仕込みモノマー分率 0.2 で行ったか， 1 と 3 と のアニオン共重合の場合と巽なり, 共重合はもちろん, それぞれの単独重合も牒制され，高収率では重合体を得 ることはできなかった 生成重合体中の BOL 単位も， 1 の高温での単独アニオン重合を長時間行った場合と同 様に ${ }^{2), 17)}$, 複雑な異性化反応を経て不溶化した. 1 は7 員環ラクタムと 5 員環ラクタムとの両方の骨格をむつ が， 7 員環ラクタムの ラクタムの3に比較的その重合反応性が似ており，また 生成ポリアミドも相溶性が高いものと思われる。

謝辞砷議と助言をいただいた H.K. Hall，Jr. 教 授に謝意を表します。

\section{文献}

1) H. Sumitomo, K. Hashimoto, and M. Ando, J. Polym. Sci., Polym. Lett. Ed., 11, 635 (1973). 
2) H. Sumitomo and K. Hashimoto, Macromolecules, 10, 1327 (1977).

3) 住友 宏, 橋本和彦, 高分子論文集, 34, 747 (1977).

4) H. Sumitomo, K. Hashimoto, and T. Ohyama, Polym. Bull. (Berlin), 1, 133 (1978).

5) 松倉利夫, 木下隆利, 海沢 章, 辻田義治, 住 友 宏, 灀本和彦，高分子論文集， 35，803 (1978).

6) H. Sumitomo, K. Hashimoto, and T. Ohyama, Polym. Bull. (Berlin), 1, 635 (1979).

7) K. Hashimoto and H. Sumitomo, Macromolecules, 13, 786 (1980).

8) H. Sumitomo and K. Hashimoto, "Contemporary Topics in Polymer Science", Vol. 4, Plenum, New York, 印刷中.

9) 井本 稔. “合成高分子 V” (村橋俊介, 井本 稔, 谷 久也編), 朝倉書店, 東京 (1971), p.
115.

10) J. Sebenda, J. Macromol. Sci.-Chem., A6, 1145 (1972).

11) S. Bar-zakay, M. Levy, and D. Vofsi, J. Polym. Sci., $A-1$, 5, 965 (1967).

12) G. Schirawski, Makromol. Chem., 161, 69 (1972).

13) J. Kondelíková, J. ̌̌ejba, Z. Černy̌, and J. Králíček, Makromol. Chem., Rapid Commun., 1, 35 (1980) and the preceding papers.

14) H. Sekiguchi, Bull. Soc. Chim. Fr., 1827 (1960).

15) H. K. Hall, Jr., M. K. Brandt, and R. M. Mason, J. Am. Chem. Soc., 80, 6420 (1958).

16) H. K. Hall, Jr., J. Am. Chem. Soc., 80, 6404 (1958).

17) K. Hashimoto and H. Sumitomo, unpublished data.

\section{Ring-Opening Anionic Copolymerization of Bicyclic Oxalactam with 2-Pyrrolidone}

Hiroshi Sumitomo, ${ }^{* 1}$ Kazuhiko Hashimoto, ${ }^{* 1}$ and Yasuhiro BetsudA*2

*1Faculty of Agriculture, Nagoya University (Furo-cho, Chikusa-ku, Nagoya 464 Japan).

*2Faculty of Agriculture, Nagoya University (present: Shinwaseisakusho, 1750, Kosugaya-cho, Totsuka-ku, Yokohama, 247 Japan).

Anionic ring-opening copolymerization of bicyclic oxalactam, 8-oxa-6-azabicyclo[3.2.1]octan-7-one (abbreviated as $\mathrm{BOL}$ ), with 2-pyrrolidone was carried out in bulk at $40-60^{\circ} \mathrm{C}$ with the use of potassium pyrrolidonate and $\mathrm{N}$-acetyl BOL as a catalyst and an activator, respectively. The ultimate conversion attained at $40^{\circ} \mathrm{C}$ was higher than that at $60^{\circ} \mathrm{C}$. The qualitative polymerizability of BOL was found, from the analytical data on the composition of the polymer, to be higher than that of 2-pyrrolidone in the present conditions. The ${ }^{13} \mathrm{C} N M R$ analysis of the polymer showed that both monomer units are linked at random throughout the polymer chain.

KEY WORDS Bicyclic Oxalactam / 8-Oxa-6-azabicyclo[3.2.1]octan-7-one / 2-Pyrrolidone / Copolymerization /

Ring-Opening Polymerization / Copolyamide /

(Received June 18, 1982: Accepted August 24, 1982)

[Kobunshi Ronbunshu, 39 (12), 807-811 (1982)] 